Dr. Kari Beate Remmen's work focuses on geoscience education at the Norwegian Centre for Science Education, University of Oslo, Norway. This involves developing teaching materials, teacher professional development courses, and research. This article is a synthesis of her PhD thesis on geoscientific fieldwork in upper secondary school, which she defended January 2014 .

Merethe Frøyland is Associate Professor at the Norwegian Centre for Science Education, University of Oslo, Norway. Her research and development focuses on geoscience education from primary to upper secondary levels. She is also leading a research - and development project on science centers at the Norwegian University of Life Sciences.

KARI BEATE REMMEN

The Norwegian Center for Science Education (Naturfagsenteret)/University of Oslo, Norway

k.b.remmen@naturfagsenteret.no

MERETHE FR $\varnothing$ YLAND

The Norwegian Center for Science Education (Naturfagsenteret)/University of Oslo, Norway

merethe.froyland@naturfagsenteret.no

\title{
Supporting student learning processes during preparation, fieldwork and follow-up work: Examples from upper secondary school in Norway
}

\begin{abstract}
Fieldwork can enrich students' science learning. In the context of a research project on geoscientific fieldwork for upper secondary students in Norway, this article discusses how student learning processes can be supported throughout sequences of classroom and fieldwork activities. Video observation of activities, instructional artifacts and teacher interviews were collected from three teachers and their students. The data analyses address: (1) the implementation of recommendations for fieldwork, and (2) the nature of student learning processes. After analyzing six cases of fieldwork including classroom preparation and follow-up work, we found only one case in which the students showed deeper learning processes and the teacher was satisfied with the activities and the students' learning outcome. Therefore, the recommendations for fieldwork did not function as intended. The discussion focuses on the most successful case to see if recommendations for fieldwork can be reconsidered in order to support student learning processes more effectively.
\end{abstract}

\section{INTRODUCTION}

Educational fieldwork in settings such as nature and museums can promote student motivation, knowledge and skills in and about science (Braud \& Reiss, 2006). To exploit this learning potential, teachers are recommended to prepare the students for the fieldwork, allow student-centered field activities, and follow-up on students' learning back in the classroom (DeWitt \& Storksdieck, 2008; Rickinson et al., 2004). However, studies have shown that teachers to not follow the recommendations; student preparation and follow-up work are often insufficiently addressed, and the pedagogy during the fieldwork is teacher-centered (Oost, De Vries, \& Van der Schee, 2011). Reasons for this include time constraints, curriculum-load, strict time tables, lack of financial resources, safety issues, 
school culture, low student motivation and low confidence in teaching outside the classroom (Koller, 2009; Magntorn \& Helldén, 2006; Oost et al., 2011; Scott, Boyd, Scott \& Colquhoun, 2014). Such findings have led researchers to call for more knowledge about how outdoor science activities can be implemented more effectively (DeWitt \& Storksdieck, 2008; Tal, Alon \& Morag, 2014).

Therefore, in our research project, we used a different approach than the above studies: we investigated what happened to student learning processes when teachers actually implemented geoscientific fieldwork including classroom preparation and follow-up work (Remmen \& Frøyland, 2013; 2014; 2015). One key finding was that the learning activities did not always contribute largely to student learning processes. This finding evoked a need for more knowledge about how student learning can be supported more effectively across preparation, fieldwork and follow-up work. The present article aims to address this issue by synthesizing and extending our previous video studies of geoscientific fieldwork undertaken by three teachers and their students in upper secondary school in Norway.

In the first section, we outline the recommendations for school-based fieldwork and similar outdoor activities described in the literature. This literature was presented to the teachers on a professional development course focusing on geoscience and fieldwork pedagogy, and informed our subsequent analyses of the teachers' implementation of learning activities. Next, we describe the analytical framework that was used to investigate the nature of student learning processes while undertaking learning activities afforded by their teacher. Lastly, we review our recent studies to provide a background for the focus and the research questions addressed in the present article.

\section{RECOMMENDATIONS FOR SCHOOL-BASED FIELDWORK}

Several theoretical models, frameworks, and guidelines have been suggested by scholars to support teachers and educators to implement fieldwork and related outdoor activities (DeWitt \& Osborne, 2007; Frøyland, 2010; Kent, Gilbertson \& Hunt, 1997; Morag \& Tal, 2012; Orion, 1993). This literature recommends teachers to have a clear purpose of the outdoor activity (usually alignment with curriculum goals), and integrate fieldwork with classroom activities in three phases: preparation, the fieldwork activity itself, and follow-up work. Each phase is elaborated below.

Preparation enhances student learning during the outdoor activity (DeWitt \& Storksdieck, 2008). Orion (1993) recommends teachers to include three aspects in the preparation of students: cognitive, geographical and psychological. Cognitive preparation involves presenting concepts and materials students will encounter during the fieldwork. Psychological preparation involves information about the schedule, tasks and how to use equipment. Geographical preparation is ensured by having students to study maps of the fieldwork setting.

The fieldwork should take place in settings within short distance from the school to save time and administration (Orion, 1993). The learning activities should, according to a socio-cultural perspective, encourage students' social interactions and direct experiences with concrete objects and phenomena through observation, identification and touching (Tal et al., 2014). Such student-centered activities must also allow students to make choices and take control of their learning process. Choice and control can be promoted by "limited choice" learning activities which means to allow students to choose, for example, order of objects and tasks, and time spent on each object (Bamberger \& Tal, 2007).

After the field activity, follow-up work in the classroom is recommended because students need extra time and resources to reflect on and theorize their experiences (Orion, 1993). In this process, students should synthesize and visualize their learning in an end product - such as a presentation or report (DeWitt \& Osborne, 2007). Teachers can use end products to assess student learning (Kent et al., 1997). 


\section{TEACHING FOR UNDERSTANDING AND THINKING MOVES}

Fieldwork implemented according to the recommendations outlined above can potentially promote deep-level learning among students (Mogk \& Goodwin, 2012; Oost et al., 2011). A deep learning process is driven by motivation and interest in the task and involves linking different parts of knowledge together, such as examples with generalizations, and new concepts to everyday situations (Entwistle \& Smith, 2002). By contrast, memorization of information from textbooks and authoritative sources without reflecting on the meaning or relating the knowledge to other tasks or ideas is deemed as a superficial learning process (Entwistle \& Smith, 2002). Deeper learning increases the likelihood that students will activate and apply their knowledge in new and more complex situations. When they do so, they are also demonstrating and developing their understanding (Wiske, 1998). This idea of knowledge application aligns with the idea of field-based learning as a cumulative process (Orion, 1993). That is, fieldwork involves learning content during preparation that can be applied in the field, and gaining experiences in the field that can be built on by follow-up activities. This process can foster deeper understanding of scientific knowledge.

To clarify "deeper learning processes", Ritchhart, Church and Morrison (2011:11-13) introduced the concept of thinking moves as intellectual actions particularly useful for developing understanding. Specifically, the thinking moves are: observing closely and describe what's there, building explanations and interpretations, making connections, capturing the heart and forming conclusions, wondering and asking questions, considering different viewpoints and perspectives, uncovering complexities and going below surface of things, and reasoning with evidence.

The thinking moves listed above are generic, but similar frameworks exist in science education literature. For example, close observation and using evidence in interpretation and reasoning are elements of inquiry processes (Crawford, 2014). It can therefore be expected that the thinking moves can be applied to investigate learning processes in science as well. However, students' thinking moves cannot be observed directly, but their talk and actions in learning situations can be considered as indicators of their thinking (Wiske, 1998).

\section{THE FOCUS OF STUDY AND RESEARCH QUUESTIONS DERIVED FROM THE RESEARCH PROJECT ON GEOSCIENCE FIELDWORK}

In our research project on geoscience in upper secondary school, the recommendations described above were applied by three teachers and their students. Our analyses of video data from the implementation resulted in the following key findings (Remmen \& Frøyland, 2013; 2014; 2015):

- When two of the teachers implemented preparation, "limited choice" field activities, and followup work, the student learning processes were predominantly superficial.

- The teacher who chose a field setting within walking distance from the school avoided the common obstacles associated with fieldwork - such as time and costs.

- The students who were given one, focused task in the field showed deeper engagement than student who were assigned a worksheet with many close-ended questions.

- Although one teacher supported the students by talk and questioning, the students' learning process was mainly superficial. Another teacher had a more withdrawn role in terms of talk and questioning, but the students' were deeper engaged in their activities.

- The students had difficulties with observing and interpreting objects and phenomena in the field - despite that they had been exposed to thorough and varied preparation activities. One reason for this, we discuss, was that the students had not gained appropriate mental tools for applying geological concepts in the field. Specifically, we suggested that students need tools for observation and interpretation, which include information about what features to look for and what it means in a geoscientific sense.

- During follow-up work, the students were primarily focused on procedural aspects of the tasks 
or engaged in off-task matters. However, deep-level learning processes appeared among students who were required to apply their field observations to make a decision about an open, real-life problem.

As indicated by the findings above, geoscience fieldwork did not always lead to deeper learning processes among the students. This contrasts with the assumption that fieldwork provides a deep learning experience (Braund \& Reiss, 2006; Mogk \& Goodwin, 2012). Therefore, the present article addresses how teachers can support deeper student learning processes throughout classroom preparation, fieldwork and classroom follow-up work. In doing so, we include a larger amount of data than our previous work to explore two research questions (RQ's):

RQ1) How did the teachers implement the recommendations for fieldwork?

RQ2) What was the nature of student learning processes while undertaking the learning tasks during preparation, fieldwork and follow-up work?

\section{MetHOdS}

This section describes the research process, from the selection of teachers from a professional development course on geoscience fieldwork, to data collection from the implementation of classroom and field activities, and the data analyses.

\section{The teacher professional development course on geoscientific fieldwork}

The in-service teachers were selected from a one-year teacher professional development course (henceforth: TPD) focusing on geoscience fieldwork. The TPD was voluntarily, suggesting that the teachers had a particular motivation for increasing their competence in fieldwork teaching. During the TPD course meetings, the recommendations reviewed above; preparation, "limited choice" field activities, and follow-up work; were implemented by the course leaders (second author). Between the course meetings, the teachers transferred the recommendations to design and implement fieldwork with their students. After the course, we invited three teachers; who were particularly enthusiastic about geoscientific fieldwork; to participate in our research project. This enabled us to study the student responses to the learning activities when the teachers practiced the recommendations for fieldwork.

\section{The teachers and the students}

The three teachers and their class of students (aged 17-19) came from three different schools situated in different regions in Norway. Details about the classes - labelled class A, B, and C - are summarized in Table 1.

Table 1. The classes, teachers, and students involved in the research.

\begin{tabular}{|l|l|l|}
\hline Class & $\begin{array}{l}\text { Teacher* (years of teaching experience, years } \\
\text { of teaching experience in geoscience) }\end{array}$ & Students (grade) (girls, boys) \\
\hline A & Lars $(15,3)$ & $(12),(4,13)$ \\
\hline B & Ane $(10,3)$ & $(13),(4,5)$ \\
\hline C & Ida $(3,2)$ & $(13),(9,4)$ \\
\hline
\end{tabular}

* The teachers had maximum three years of teaching experience in geoscience because the subject was introduced as a new optional science specialization subject in the latest curriculum reform in 2006. 


\section{Data collection}

We followed the three teachers and their students throughout one school year. The teachers notified us when they planned to conduct fieldwork, so we could visit them to collect data. Video data was collected by equipping the teachers and two students in each class with a head-mounted camera (HD GoProß). This camera recorded the activities across time and settings: preparation, fieldwork, and follow-up work, and in some cases; student oral presentations. Although one student carried the camera on his/hers head, the camera recorded the whole team during the learning activities (3-4 students in each team $\mathrm{x}$ two teams in each class $\mathrm{x}$ three classes $=18$ students in total). Three headmounted cameras were in operation simultaneously in each class, producing 130 hours of video data in total. Instructional artifacts created during the activities (e.g., student field notes and teachers' hand-outs) were also collected and analyzed together with the video data. Supplementary data were obtained from interviews with the teachers prior to and after the implementation. We were present as observers during all activities, which increased our knowledge about the contexts and facilitated the subsequent video analysis (Derry et al., 2010).

\section{Data analyses}

To answer RQ1, seven recommendations (numbered 1-7) for fieldwork derived from the literature review were applied to analyze the data.

1. The purpose of fieldwork

2. Field setting within close distance from the school

3. Cognitive, geographical, and psychological preparation

4. "Limited choice" field activity

5. Follow-up work

6. Student end product

7. Assessment of student learning

The interview with the teacher before the implementation provided information about the purpose of fieldwork (recommendation one). Using the video records from the teachers' head-mounted camera and instructional artifacts (e.g., hand-outs, worksheets), we considered how the learning activities corresponded to the recommendations 2-6. The interview data collected after the implementation provided information about recommendation seven. Finally, the teachers' reflections on the implementation during the interviews were compared with the video analysis.

For RQ2, regarding the student learning processes while undertaking the learning activities offered by their teacher, we screened the video tapes obtained from the student head-mounted cameras and instructional artifacts such as student field notes and written responses to tasks. Because students' observable actions are indicators of their thinking and understanding (Wiske, 1998), we considered whether students' talk (conversational turns) and written products (field notes, response to tasks) containing geoscientific content reflected one or more of the thinking moves in Table 2. Typically, thinking moves were discernable in longer, complex conversations between students. By contrast, student actions involving short and fragmented conversations, copying information from teachers and textbooks, memorizing information to answer teacher questions, were inconsistent with thinking moves and hence characterized as surface learning (Ritchhart et al., 2011). Additionally, non-verbal actions provided supportive indications of students' thinking. For example, students staring blankly around reflected an absence of thinking moves. 
Table 2. Thinking moves applied to analyze the students' learning processes while undertaking the learning tasks.

\begin{tabular}{|c|c|}
\hline $\begin{array}{l}\text { Thinking moves (Ritchhart et } \\
\text { al., 2011:11-13) }\end{array}$ & $\begin{array}{l}\text { Descriptions of students' thinking moves based on Ritchhart et } \\
\text { al., (2011:11-13). }\end{array}$ \\
\hline $\begin{array}{l}\text { Observing closely and describ- } \\
\text { ing what's there }\end{array}$ & $\begin{array}{l}\text { Students notice essential parts and features, describing them } \\
\text { fully and in detail. }\end{array}$ \\
\hline $\begin{array}{l}\text { Building explanations and } \\
\text { interpretations }\end{array}$ & $\begin{array}{l}\text { Students build explanations and interpretations of the observa- } \\
\text { tions by drawing on theoretical knowledge. }\end{array}$ \\
\hline Reasoning with evidence & $\begin{array}{l}\text { Building explanation and interpretation requires students to } \\
\text { reason with evidence to support the position and arrive at a } \\
\text { reasonable, justified solution. }\end{array}$ \\
\hline Making connections & $\begin{array}{l}\text { When students encounter something new, they make connec- } \\
\text { tions between the new and known to find out where the new } \\
\text { ideas fit in. Making connections also includes applying new ideas, } \\
\text { comparing and contrasting, and making analogies. }\end{array}$ \\
\hline $\begin{array}{l}\text { Considering different view- } \\
\text { points and perspectives }\end{array}$ & Students consider an idea from different perspectives. \\
\hline $\begin{array}{l}\text { Capturing the heart and } \\
\text { forming conclusions }\end{array}$ & Students capture the core of a concept, procedure, event, or work. \\
\hline $\begin{array}{l}\text { Wondering and asking ques- } \\
\text { tions }\end{array}$ & $\begin{array}{l}\text { Students develop their learning through wonderment, curiosity, } \\
\text { and questioning. By asking questions, students reveal the depth } \\
\text { of their understanding. }\end{array}$ \\
\hline $\begin{array}{l}\text { Uncovering complexity and } \\
\text { going below the surface of } \\
\text { things }\end{array}$ & $\begin{array}{l}\text { Rather than looking for or accepting easy answers, students try } \\
\text { to dig deeper into an idea. }\end{array}$ \\
\hline
\end{tabular}

\section{Summary of data sources and analysis}

The connection between research questions, data sources, observed unit and analysis is summarized in Table 3. 
Table 3. The connection between research questions, data sources, observed unit and analysis.

\begin{tabular}{|c|c|c|c|}
\hline Research question & Data source & Observed unit & Data analysis \\
\hline \multirow[t]{2}{*}{$\begin{array}{l}\text { RQ1) Teachers' } \\
\text { implementation of } \\
\text { recommendations } \\
\text { for fieldwork }\end{array}$} & $\begin{array}{l}\text { Video data recorded by the } \\
\text { teachers' head-mounted } \\
\text { camera } \\
\text { Instructional artifacts pro- } \\
\text { vided by the teachers }\end{array}$ & $\begin{array}{l}\text { Learning activities } \\
\text { offered by the teacher } \\
\text { (presented orally or on } \\
\text { paper) }\end{array}$ & $\begin{array}{l}\text { Recommendation for } \\
\text { fieldwork }(2-6)\end{array}$ \\
\hline & $\begin{array}{l}\text { Interview prior to the im- } \\
\text { plementation } \\
\text { Interview after the imple- } \\
\text { mentation }\end{array}$ & $\begin{array}{l}\text { The teachers' } \\
\text { responses } \\
\text { The teachers' } \\
\text { responses }\end{array}$ & $\begin{array}{l}\text { Recommendation } \\
\text { (1): The purpose of } \\
\text { fieldwork } \\
\text { Recommendation } \\
\text { (7): Assessment of stu- } \\
\text { dent learning }\end{array}$ \\
\hline $\begin{array}{l}\text { RQ2) The nature of } \\
\text { student learning } \\
\text { processes }\end{array}$ & $\begin{array}{l}\text { Video data recorded by } \\
\text { student head-mounted } \\
\text { cameras (two cameras in } \\
\text { each class) } \\
\text { Instructional artifacts (e.g., } \\
\text { written responses to tasks, } \\
\text { field notes, Power Points }{ }^{\top M} \text { ) }\end{array}$ & $\begin{array}{l}\text { Students' talk (con- } \\
\text { versational turns) and } \\
\text { actions during learning } \\
\text { activities } \\
\text { Students' writing (sen- } \\
\text { tences) during learning } \\
\text { activities }\end{array}$ & $\begin{array}{l}\text { Thinking moves } \\
\text { (Table 2) }\end{array}$ \\
\hline
\end{tabular}

\section{FINDINGS}

The first section summarizes the teachers' implementation of recommendations for fieldwork (RQ1), and the nature of student learning processes while undertaking their learning tasks (RQ2). Then, two cases are described in detail to facilitate the discussion about the recommendations for fieldwork.

\section{The teachers' implementation of fieldwork and the students' learning processes}

Overall, the three teachers implemented fieldwork six times in total throughout one school year. All times, the fieldwork aligned with the seven recommendations in the literature. However, there was a considerable variation in how the recommendations were implemented. The teacher in class A implemented fieldwork one time in geology (henceforth: case A1). The fieldwork itself was organized as a full day fieldtrip to a Geo Park which required transportation of students by coach. In class B, the teacher Ane implemented fieldwork two times (henceforth: case B1 and B2), whereas Ida conducted fieldwork three times (henceforth: case $\mathrm{C}_{1}, \mathrm{C}_{2}$, and $\mathrm{C}_{3}$ ). Both Ane and Ida chose field settings within walking distance from the school, and the field activities were undertaken during one regular lesson (80 minutes).

Regarding the students, there was also a considerable variation in the nature of the learning processes. Thinking moves were most prominent among the students in class C. By contrast, the students in case A1, B2, and B2 showed limited evidences of thinking moves. They focused more on practicalities than geoscientific content, and during the activities, they asked the teacher or checked the Internet for answers or gave up completing the tasks. Hence, the absence of thinking moves in the students' learning processes occurred despite the fact that their teachers implemented fieldwork according to the seven recommendations.

The absence of thinking moves; which indicates superficial learning; was supported by the teachers' interview following the implementation. In five of six cases, the teachers were disappointed about their students' learning outcome. However, the exception was case C2: the teacher Ida expressed satisfaction with the activities and student learning. 
To summarize, the following situation emerged - particularly in case A1, B1, and B2: although the teachers implemented fieldwork according to the recommendations, there were scarce evidences of thinking moves in the students' learning processes, and the teachers were disappointed about the students' learning outcomes. C2 appeared to be the most successful case, as evident by thinking moves recognized in the student learning processes and the teacher's expressed satisfaction. Therefore, to understand why the cases differed, we present one successful case (C2) and one less successful case (B2) in more detail. These two cases were selected because of their similarities: both addressed the topic geo resources, the field activity was conducted in an urban setting within walking distance from the school, and it was the second time the classes implemented fieldwork that school year.

\section{Case B2. Identifying geo resources in the local town}

Table 4 presents Ane's implementation of the recommendations and how the students' responded to the activities. Note that evidence of thinking moves in the students' talk and actions were rare.

Table 4. Findings from the implementation of recommendations and student learning processes in case B2.

\begin{tabular}{|c|c|c|c|}
\hline $\begin{array}{l}\text { Recommen- } \\
\text { dations for } \\
\text { fieldwork (1-7) }\end{array}$ & $\begin{array}{l}\text { RQ1: Teacher's implemen- } \\
\text { tation of recommenda- } \\
\text { tions }\end{array}$ & $\begin{array}{l}\text { RQ2: Student learning } \\
\text { processes }\end{array}$ & $\begin{array}{l}\text { Thinking moves identi- } \\
\text { fied in student talk and } \\
\text { writing (Table 2) }\end{array}$ \\
\hline $\begin{array}{l}\text { (1) The purpose } \\
\text { of the fieldwork }\end{array}$ & $\begin{array}{l}\text { Cover curriculum goals } \\
\text { about fieldwork inquiry } \\
\text { and geo resources. }\end{array}$ & & \\
\hline (2) Field setting & $\begin{array}{l}\text { Local town within walking } \\
\text { distance from the school. }\end{array}$ & & \\
\hline $\begin{array}{l}\text { (3) Preparation } \\
\text { (Classroom) }\end{array}$ & $\begin{array}{l}\text { Time: one lesson. Ane gave } \\
\text { a lecture about various } \\
\text { geo resources (i.e., natural } \\
\text { stone, ore, industrial min- } \\
\text { erals, raw materials). }\end{array}$ & $\begin{array}{l}\text { The students listened to } \\
\text { Ane's lecture, and gave } \\
\text { brief answers to teacher } \\
\text { questions. }\end{array}$ & $\begin{array}{l}\text { Listening to and an- } \\
\text { swering close-ended } \\
\text { teacher questions do } \\
\text { normally not require } \\
\text { thinking moves. }\end{array}$ \\
\hline $\begin{array}{l}\text { (4) "Limited } \\
\text { choice" field } \\
\text { activity (in the } \\
\text { local town) }\end{array}$ & $\begin{array}{l}\text { Time: one lesson. The field } \\
\text { activity was carried out } \\
\text { in the local town within } \\
\text { walking distance from the } \\
\text { school. } \\
\text { The students worked in } \\
\text { teams with the following } \\
\text { task: Look for geo resourc- } \\
\text { es and take pictures. What } \\
\text { resource is it? How was it } \\
\text { formed? Where is it mined? } \\
\text { Can it be used for other } \\
\text { purposes? What are the } \\
\text { environmental conse- } \\
\text { quences of the mining? } \\
\text { The teacher circulated } \\
\text { among the teams to } \\
\text { support their learning } \\
\text { process. }\end{array}$ & $\begin{array}{l}\text { The students wandered } \\
\text { around the town and } \\
\text { found many examples } \\
\text { of geo resources. Typi- } \\
\text { cally, one student took } \\
\text { picture and the team } \\
\text { tried to identify it: "It is } \\
\text { gneiss", “This is gran- } \\
\text { ite... isn't it?". Often, the } \\
\text { name was wrong, and } \\
\text { not justified. } \\
\text { When prompted by the } \\
\text { teacher, they responded } \\
\text { with silence, or guessed } \\
\text { "granite..?", or "I have no } \\
\text { idea”, } \\
\text { Apart from these ob- } \\
\text { servations, off-task talk } \\
\text { prevailed. }\end{array}$ & $\begin{array}{l}\text { When prompted and } \\
\text { supported by the } \\
\text { teacher, there were a } \\
\text { few weak indications of } \\
\text { thinking moves. }\end{array}$ \\
\hline
\end{tabular}

table cont. 
Table 4 cont. Findings from the implementation of recommendations and student learning processes in case B2.

\begin{tabular}{|l|l|l|l|}
\hline $\begin{array}{l}\text { Recommen- } \\
\text { dations for } \\
\text { fieldwork (1-7) }\end{array}$ & $\begin{array}{l}\text { RQ1: Teacher's implemen- } \\
\text { tation of recommenda- } \\
\text { tions }\end{array}$ & $\begin{array}{l}\text { RQ2: Student learning } \\
\text { processes }\end{array}$ & $\begin{array}{l}\text { Thinking moves identi- } \\
\text { fied in student talk and } \\
\text { writing (Table 2) }\end{array}$ \\
\hline $\begin{array}{l}\text { (5) Follow-up } \\
\text { work (Class- } \\
\text { room) }\end{array}$ & $\begin{array}{l}\text { Time: one lesson. Ane } \\
\text { asked the teams to com- } \\
\text { plete the field task quoted } \\
\text { above. She provided addi- } \\
\text { tional learning resources } \\
\text { (i.e., geology books), and } \\
\text { posed questions to the } \\
\text { students like, "What geo } \\
\text { resources is that?», "How } \\
\text { was it formed"? }\end{array}$ & $\begin{array}{l}\text { The students distrib- } \\
\text { student "googled" facts } \\
\text { about the geo resources } \\
\text { photographed during } \\
\text { the fieldwork, while } \\
\text { another student pasted } \\
\text { pictures to make a } \\
\text { poster. Other students } \\
\text { did nothing. }\end{array}$ & $\begin{array}{l}\text { Indications of think- } \\
\text { ing moves were weak } \\
\text { since the students were } \\
\text { focused on procedural } \\
\text { matters with the poster } \\
\text { or dependent on Inter- } \\
\text { net etc. to complete } \\
\text { their task. }\end{array}$ \\
\hline $\begin{array}{l}\text { (6) Student end } \\
\text { product }\end{array}$ & $\begin{array}{l}\text { The teacher required the } \\
\text { students to make a poster } \\
\text { of the geo resources iden- } \\
\text { tified in the local town }\end{array}$ & $\begin{array}{l}\text { The students did not } \\
\text { manage to finish the } \\
\text { poster. }\end{array}$ & $\begin{array}{l}\text { No findings since there } \\
\text { was no end product }\end{array}$ \\
\hline $\begin{array}{l}\text { (7) Assessment } \\
\text { of student } \\
\text { learning }\end{array}$ & $\begin{array}{l}\text { The students were tested } \\
\text { on a local trial exam. }\end{array}$ & & \\
\hline
\end{tabular}

\section{Case C2. Choose building stones for the Opera house}

Table 5 shows Ida's implementation of the recommendations and the nature of the student learning processes during the activities. Note that several thinking moves were identified in the analysis of students' talk and actions.

Table 5. Findings from the implementation of recommendations and student learning processes in case $\mathrm{C} 2$.

\begin{tabular}{|l|l|l|l|}
\hline $\begin{array}{l}\text { Recommen- } \\
\text { dations for } \\
\text { fieldwork }\end{array}$ & $\begin{array}{l}\text { RQ1: Teacher's imple- } \\
\text { mentation of recom- } \\
\text { mendations }\end{array}$ & $\begin{array}{l}\text { RQ2: Student learning pro- } \\
\text { cesses }\end{array}$ & $\begin{array}{l}\text { Thinking moves identi- } \\
\text { fied in student talk and } \\
\text { activity (Table 2) }\end{array}$ \\
\hline $\begin{array}{l}\text { (1) The purpose } \\
\text { of the field- } \\
\text { work }\end{array}$ & $\begin{array}{l}\text { Address curriculum } \\
\text { goals about geo } \\
\text { resources through an } \\
\text { open inquiry }\end{array}$ & & \\
\hline $\begin{array}{l}\text { (2) Field set- } \\
\text { ting }\end{array}$ & $\begin{array}{l}\text { The Opera House and } \\
\text { the Natural history } \\
\text { museum - both within } \\
\text { walking distance from } \\
\text { the school }\end{array}$ & & \\
\hline
\end{tabular}

table cont. 
Table 5 cont. Findings from the implementation of recommendations and student learning processes in case C2.

\begin{tabular}{|c|c|c|c|}
\hline $\begin{array}{l}\text { Recommen- } \\
\text { dations for } \\
\text { fieldwork }\end{array}$ & $\begin{array}{l}\text { RQ1: Teacher's imple- } \\
\text { mentation of recom- } \\
\text { mendations }\end{array}$ & $\begin{array}{l}\text { RQ2: Student learning pro- } \\
\text { cesses }\end{array}$ & $\begin{array}{l}\text { Thinking moves identi- } \\
\text { fied in student talk and } \\
\text { activity (Table 2) }\end{array}$ \\
\hline $\begin{array}{l}\text { (3) Preparation } \\
\text { (Classroom) }\end{array}$ & $\begin{array}{l}\text { Time: one lesson. } \\
\text { Ida's preparation for } \\
\text { fieldwork began with } \\
\text { the problem: What do } \\
\text { you think is the advan- } \\
\text { tages and detriments } \\
\text { with the rocks/building } \\
\text { stones at the Opera } \\
\text { House? Assume that you } \\
\text { use a Norwegian rock } \\
\text { - which one would you } \\
\text { choose and why? }\end{array}$ & $\begin{array}{l}\text { Before choosing a rock, the } \\
\text { students checked websites } \\
\text { of Norwegian geologi- } \\
\text { cal survey and various } \\
\text { textbooks. They assessed } \\
\text { cons and pros for each } \\
\text { alternative with respect } \\
\text { to resistance, accessibility, } \\
\text { and transport distance. } \\
\text { Disagreement extended } \\
\text { the discussion before se- } \\
\text { lecting a Norwegian rock } \\
\text { like larvikite. }\end{array}$ & $\begin{array}{l}\text { Corresponding thinking } \\
\text { moves: } \\
\text { - Considering different } \\
\text { viewpoints and per- } \\
\text { spectives } \\
\text { - Making connections } \\
\text { - Capturing the heart } \\
\text { and forming conclu- } \\
\text { sions }\end{array}$ \\
\hline $\begin{array}{l}\text { (4) “Limited } \\
\text { choice" field } \\
\text { activity (at the } \\
\text { Opera house) }\end{array}$ & $\begin{array}{l}\text { Time: one lesson. } \\
\text { At the Opera house, Ida } \\
\text { gave the following task: } \\
\text { Identify three spots you } \\
\text { think display weakness- } \\
\text { es in the rocks. Describe } \\
\text { what you see in your } \\
\text { field notes. Take picture } \\
\text { Make a hypothesis of } \\
\text { what you think will hap- } \\
\text { pen to the weaknesses in } \\
\text { the future. } \\
\text { Ida had a withdrawn } \\
\text { role during the field- } \\
\text { work. }\end{array}$ & $\begin{array}{l}\text { The students walked } \\
\text { around and crawled on } \\
\text { their knees to observe } \\
\text { cracks and dirt on the rocks. } \\
\text { They wondered about the } \\
\text { reasons for weaknesses in } \\
\text { the rocks - for instance: } \\
\text { "If you spill coffee on the } \\
\text { marble, will it be discolor- } \\
\text { ed?" } \\
\text { They discussed reasons for } \\
\text { the weaknesses, such as } \\
\text { weathering, wear and tear. } \\
\text { Selecting three places in- } \\
\text { volved comparing different } \\
\text { alternatives to find the best } \\
\text { evidence of weaknesses. }\end{array}$ & $\begin{array}{l}\text { Corresponding thinking } \\
\text { moves: } \\
\text { - Observing closely } \\
\text { and describe what's } \\
\text { there } \\
\text { - Wondering and as- } \\
\text { king questions } \\
\text { - Building explanati- } \\
\text { ons and interpreta- } \\
\text { tions } \\
\text { - Considering different } \\
\text { viewpoints and per- } \\
\text { spectives. } \\
\text { - Making connections }\end{array}$ \\
\hline $\begin{array}{l}\text { (5) Follow-up } \\
\text { work (Class- } \\
\text { room) }\end{array}$ & $\begin{array}{l}\text { Time: one lesson. } \\
\text { Ida asked the students } \\
\text { to present their choice } \\
\text { of Norwegian rock. }\end{array}$ & $\begin{array}{l}\text { The teams presented their } \\
\text { choice and justification to } \\
\text { the rest of the class - for } \\
\text { instance: } \\
\text { "We chose larvikite be- } \\
\text { cause it's local, nice color, } \\
\text { resistant to air pollution } \\
\text { and weathering, easy to } \\
\text { cleave." } \\
\text { One team had changed } \\
\text { their mind after the obser- } \\
\text { vations of the rocks at the } \\
\text { Opera house. }\end{array}$ & $\begin{array}{l}\text { Corresponding thinking } \\
\text { moves: } \\
\text { - Capturing the heart } \\
\text { and forming conclu- } \\
\text { sions } \\
\text { - Making connections } \\
\text { - Building explanati- } \\
\text { ons and interpreta- } \\
\text { tion }\end{array}$ \\
\hline
\end{tabular}

table cont. 
Table 5 cont. Findings from the implementation of recommendations and student learning processes in case $\mathrm{C} 2$.

\begin{tabular}{|c|c|c|c|}
\hline $\begin{array}{l}\text { Recommen- } \\
\text { dations for } \\
\text { fieldwork }\end{array}$ & $\begin{array}{l}\text { RQ1: Teacher's imple- } \\
\text { mentation of recom- } \\
\text { mendations }\end{array}$ & $\begin{array}{l}\text { RQ2: Student learning pro- } \\
\text { cesses }\end{array}$ & $\begin{array}{l}\text { Thinking moves identi- } \\
\text { fied in student talk and } \\
\text { activity (Table 2) }\end{array}$ \\
\hline $\begin{array}{l}\text { (3) Preparation } \\
\text { for next field } \\
\text { activity }\end{array}$ & $\begin{array}{l}\text { Ida introduced the next } \\
\text { task: It has been decided } \\
\text { that the Opera House } \\
\text { shall be a white building } \\
\text { in granite and marble. } \\
\text { Make criteria for select- } \\
\text { ing marble and granite. }\end{array}$ & $\begin{array}{l}\text { The students wrote down } \\
\text { features they thought } \\
\text { constituted a high quali- } \\
\text { ty building stone inspired } \\
\text { from the preceding obser- } \\
\text { vations at the Opera House } \\
\text { - e.g., "resistance to harsh } \\
\text { weather conditions". }\end{array}$ & $\begin{array}{l}\text { - Building explanati- } \\
\text { ons and interpreta- } \\
\text { tions }\end{array}$ \\
\hline $\begin{array}{l}\text { (4) “Limited } \\
\text { choice" field } \\
\text { activity }\end{array}$ & $\begin{array}{l}\text { Time: one lesson. } \\
\text { At a rock collection } \\
\text { (consisting of five types } \\
\text { of granite and four } \\
\text { types of marble) at the } \\
\text { Natural history muse- } \\
\text { um, the students' task } \\
\text { was to: Describe the } \\
\text { different types of marble } \\
\text { and granite. Take field } \\
\text { notes and pictures. } \\
\text { Apply the selection } \\
\text { criteria for granite and } \\
\text { marble. Why do you } \\
\text { think the rock is a good } \\
\text { or poor building stone? } \\
\text { The students could } \\
\text { choose the order of } \\
\text { observations, and time } \\
\text { on each rock. }\end{array}$ & $\begin{array}{l}\text { The students compared the } \\
\text { different types of rocks, us- } \\
\text { ing their criteria (i.e., grass } \\
\text { stain, discolor) created in } \\
\text { the previous lesson. They } \\
\text { wrote the observations in } \\
\text { the field books and dis- } \\
\text { cussed benefits and detri- } \\
\text { ments with each rock. }\end{array}$ & $\begin{array}{l}\text { Corresponding thinking } \\
\text { moves: } \\
\text { - Observing closely and } \\
\text { describe what's there } \\
\text { - Making connections } \\
\text { - Considering different } \\
\text { viewpoints and per- } \\
\text { spectives }\end{array}$ \\
\hline $\begin{array}{l}\text { (5) Follow-up } \\
\text { work (Class- } \\
\text { room) }\end{array}$ & $\begin{array}{l}\text { Time: one lesson. } \\
\text { Ida said: Imagine that } \\
\text { the Opera House was } \\
\text { not built. You have the } \\
\text { power to decide which } \\
\text { type of marble and } \\
\text { granite to use. Use the } \\
\text { criteria for marble and } \\
\text { granite to justify your } \\
\text { choice. Also, use the } \\
\text { criteria to justify those } \\
\text { rocks you did not choose. }\end{array}$ & $\begin{array}{l}\text { The students examined } \\
\text { their field data and com- } \\
\text { pared the different granites } \\
\text { and marbles according to } \\
\text { their criteria for building } \\
\text { stones. After making a deci- } \\
\text { sion, they "googled" media } \\
\text { reports. Based on that, they } \\
\text { reconsidered their initial } \\
\text { choice, talked about the } \\
\text { costs and environmental } \\
\text { consequences of the differ- } \\
\text { ent options, and comment- } \\
\text { ed that the issue of build- } \\
\text { ing stones was interesting. }\end{array}$ & $\begin{array}{l}\text { Corresponding thinking } \\
\text { moves: } \\
\text { - Observing closely and } \\
\text { describe what's there } \\
\text { - Making connections } \\
\text { - Considering different } \\
\text { viewpoints and per- } \\
\text { spectives } \\
\text { - Capturing the heart } \\
\text { and forming conclu- } \\
\text { sions }\end{array}$ \\
\hline
\end{tabular}

table cont. 
Table 5 cont. Findings from the implementation of recommendations and student learning processes in case $\mathrm{C} 2$.

\begin{tabular}{|l|l|l|l|}
\hline $\begin{array}{l}\text { Recommen- } \\
\text { dations for } \\
\text { fieldwork }\end{array}$ & $\begin{array}{l}\text { RQ1: Teacher's imple- } \\
\text { mentation of recom- } \\
\text { mendations }\end{array}$ & $\begin{array}{l}\text { RQ2: Student learning pro- } \\
\text { cesses }\end{array}$ & $\begin{array}{l}\text { Thinking moves identi- } \\
\text { fied in student talk and } \\
\text { activity (Table 2) }\end{array}$ \\
\hline $\begin{array}{l}\text { (6) Student } \\
\text { end product }\end{array}$ & $\begin{array}{l}\text { Time: one lesson. } \\
\text { Oral presentation with } \\
\text { the team's decision } \\
\text { of type of marble and } \\
\text { granite as building } \\
\text { stones for the Opera } \\
\text { House. }\end{array}$ & $\begin{array}{l}\text { Without manuscripts, the } \\
\text { students presented the } \\
\text { benefits and detriments of } \\
\text { each option before giving } \\
\text { their conclusion and justi- } \\
\text { fication. }\end{array}$ & $\begin{array}{l}\text { Corresponding thinking } \\
\text { moves: } \\
\text { - Considering different } \\
\text { viewpoints and per- } \\
\text { spectives } \\
\text { - Making connections } \\
\text { Reasoning based on } \\
\text { evidence } \\
\text { The teams chose different } \\
\text { rocks, and their decision the heart } \\
\text { and forming conclu- } \\
\text { sions }\end{array}$ \\
\hline $\begin{array}{l}\text { (7) Assessment marble at the original } \\
\text { Opera house in Oslo. }\end{array}$ & $\begin{array}{l}\text { Ida gave oral feed- } \\
\text { back on students' end } \\
\text { product. }\end{array}$ & & \\
\hline
\end{tabular}

\section{Discussion}

Our study was based on the assumptions that fieldwork promotes deeper learning if teachers prepare their students and follow-up on student learning afterwards (e.g., Mogk \& Goodwin, 2012), and that thinking moves manifested in students' talk and actions reflect deep learning processes (Ritchhart et al., 2011). After analyzing six cases of preparation, fieldwork and follow-up work implemented by three different teachers, we found limited evidences of thinking moves among the students in class A and B while undertaking the tasks. Therefore, it becomes interesting that the teacher in class C implemented the same recommendations as the other two teachers, but thinking moves were more evident among her students. The difference between the students' learning processes across cases can be due to the nature of the learning tasks. Some learning tasks are more likely to foster thinking moves than others (Ritchhart et al., 2011). The two cases B2 and C2 (Table 4 and 5) demonstrate this more clearly: although both teachers implemented the recommendations for fieldwork to support student learning of geo resources, thinking moves were more apparent among the students in case $\mathrm{C}_{2}$ than in case B2. The difference in the student learning processes call into question whether the widely accepted recommendations for fieldwork used in our study are sufficient enough for enabling teachers to design learning tasks that encourage deeper learning processes throughout preparation, fieldwork, and follow-up work. Accordingly, our discussion focuses on the qualities of the learning tasks provided in case $\mathrm{C} 2$ to enable a reflection on how recommendations for fieldwork may be reconsidered to support student learning processes more effectively.

\section{Making connections: Situate the content in a realistic issue connected to the field setting}

In case $\mathrm{C} 2$, the learning tasks across preparation, fieldwork and follow-up work appeared to be parallel to an actual dispute about building stones at the Opera House in Oslo, Norway. For readers who are unfamiliar with the topic: the Italian marble used as building stone has provoked debate in the media due to ongoing problems with discolors and cracks. The teacher in our study utilized this building stone issue to contextualize the geoscientific content required by the national curriculum. Situating scientific content in relevant, real-life contexts is a recommended approach in science education (Bennett, Lubben \& Hogarth, 2007). This approach appeared to support the students' learning 
processes in several ways, as evident by the variety of thinking moves. First, the teacher used the building stone issue to ask the students about their opinion. This way, the teacher helped the students to problematize the content, which can promote deeper engagement (Engle \& Conant, 2002). Second, the students had probably heard about the building stone issue at the Opera House from the media. This familiarity could have provided additional support for the thinking move "Making connections" between prior experiences and the new learning situation. Third, the students were asked to choose building stones in the beginning and in the end of the learning sequence (Table 5). The purpose of fieldwork then was to develop the students' knowledge about building stones by having them to collect field observations and read about the issue in media reports. This approach can be seen as an operationalization of field-based learning as a cumulative process (Orion, 1993). Forth, the learning tasks framed by the real-life building stone issue helped the students to become interested in the geoscientific content, as recognized by the students' comments. Interest in the task is a necessary condition for deeper learning (Entwistle \& Smith, 2002). Situating the geoscience content in a reallife issue can be one way to stimulate students' interest in the fieldwork.

The consequence of not situating the geoscientific content in a real-life issue can be illuminated by case B2. Here, the students were not required to consider geo resources as a body of knowledge that can be applied to solve real-life issues in their local environment. The learning tasks afforded by the teacher were mostly about collecting as much information as possible - without requiring the students to form an opinion about it or to apply it to solve a realistic issue. It was therefore not surprising to find poor evidence of thinking moves among the students; such tasks are unlikely to foster deeper learning and understanding (Ritchhart et al., 2011). Similar to case C2, the students in case B2 also conducted fieldwork in a familiar setting (i.e., the local town). However, the students' learning processes in case B2 suggest that seeing examples of geo resources in their local town was not sufficient enough for exploiting the learning potential associated with fieldwork in the local environment (Knain \& Prestvik, 2006). This suggests that fieldwork has to provide something more than merely seeing geoscientific knowledge in an outdoor setting. Case C2 may provide one answer to this by showing that students can use fieldwork to suggest a solution to a real-life issue in the local environment.

Of course, most teachers do not have an Opera House with building stone problems close to their school. But we believe our findings can inspire teachers to consider whether the (geo) science content taught through fieldwork can be situated in a real-life issue. Then the purpose of the fieldwork will be to have students to collect field observations that they can later apply to make a decision or form an opinion about the issue. It does not have to be an issue that has happened in the past, as exemplified by the issue of building stones for the Opera House in the present study. It can also be a fictive, but realistic situation (Ødegaard, 2007). Furthermore, as advocated above, asking students to use field observations to develop their solution to a real-life issue can make fieldwork in a familiar setting close to the school more engaging.

\section{Observing closely and describe what's there: Tools for observation and interpretation}

Another strength of the learning tasks in case $\mathrm{C} 2$ appears to be how the students were prepared for collecting field observations. They were asked to develop general criteria for building stones (i.e., cracks, dirt, stain, discolor). These criteria for building stones helped the students to focus their attention when collecting observations in the field, as apparent by the thinking move "observing closely and describing what's there". This way, the criteria for building stones functioned as "tools for observation and interpretation" developed in our recent work (Remmen \& Frøyland, 2013). Tools for observation and interpretation can support students to know what features to look for and what it means in a geoscientific sense. This is critical because students need explicit instruction about scientifically relevant observations (Ford, 2005). From this perspective, we are uncertain whether it was a good idea to have the students to develop their own criteria for observation, as in case C2. If students do not know what features to look for, it is unlikely that they develop appropriate "tools for observa- 
tion and interpretation”. Whether such tools should be developed by students or a teacher, or both, needs to be explored by more research.

The importance of "tools for observation and interpretation" can be illuminated by a contrasting case (B2). The students' preparation consisted of a teacher-led lecture about geo resources. Because lectures usually contain a wealth of information, it might be difficult for students to filter the information they need for proceeding to field activities requiring observation. Comments like "I have no idea" and random guessing of rock names showed that the students' were uncertain about what to observe and what it meant. Therefore, to better support student learning processes in the field, we advise teachers to prioritize "tools for observation and interpretation" when preparing students for fieldwork instead of presenting all there is to know about a topic in a teacher-led lecture. Such tools can enhance productive student discussions during the forthcoming fieldwork (Remmen \& Frøyland, 2013).

\section{Considering different viewpoints and perspectives: Field task}

The students in both cases were given one field task that allowed them to make some choices (Table 4 and 5). In our recent study we found that one, focused field task was better for student learning processes than a worksheet loaded with close-ended tasks (Remmen \& Frøyland, 2014). However, because thinking moves were more apparent among the students in case $\mathrm{C}_{2}$ than in case B2, the recommendation for designing field task needs closer inspection.

The field task provided in case $\mathrm{B} 2$ required the students to choose examples of geo resources and identify them (i.e., name, formation process and so forth). Nonetheless, we observed that the students collected as many examples as possible without reflecting on it - as noticed by statements like "This is granite" and taking a picture before proceeding to the next spot. It must therefore be additional factors that influenced the student learning process than having the opportunity to make some choices. The field task in case $\mathrm{C} 2$ provides some clues. When the students were asked to identify three spots displaying weaknesses in the rocks, they had to compare alternatives to choose one of them. This appeared to stimulate the thinking moves involving close observation, making connections, and considering different viewpoints and perspectives before arriving at a conclusion. Furthermore, at the museum (Table 5), the students in case $\mathrm{C} 2$ could choose between a few alternatives (i.e., five granites and four marbles), whereas the students in case B2 had plentiful options to collect as many examples of geo resources as possible. Choosing between limited alternatives can promote more motivation and content-focus compared to choosing between unlimited alternatives (Bamberger \& Tal, 2007). Taken together, it can be proposed that the field task should allow students to make choices based on comparison of a limited number of alternatives.

\section{Follow-up tasks: Building explanations and interpretations and Capturing the heart and forming conclusions}

Returning to the classroom - the follow-up work - the students in case C2 used their field observations of various types of marble and granite to choose one of them as building stones for the Opera House. This task was open-ended and appeared to encourage actions among the students that were consistent with a variety of thinking moves, including comparing their pictures of the rocks, considering strengths and weaknesses of each marble and granite, and reflecting on environmental and economic perspectives before making a decision. In this process, the students collaborated about interpreting the field observations, which provided an opportunity for all the team members to learn from the fieldwork experience. Their learning was confirmed by the performances of the end products: their presentations without manuscripts reflected independence and ownership of their learning. These observations led us to propose that learning tasks during follow-up work should require students to make a decision and use field observations to justify their solution (Remmen \& Frøyland, 2015). 
The consequences of not having students to apply their field observations to make a decision can be illuminated by the nature of the learning process among the students in case B2, as well as findings from other studies (DeWitt \& Hohenstein, 2010; Remmen \& Frøyland, 2015). Instead of interpreting field observations in the team, the students distributed labor: one made the end product that require more procedural skills, another "googled" on the Internet for answers, while some waited for their peers to do the work. It is thus unlikely that all team members increased their learning of geo resources during the follow-up work. One reason could be that they were not required to apply their field observation for any broader purpose than finding more factual information about the geo resources they had photographed. Of course, copying and accumulating information from other sources without reflection does not support deeper learning (Ritchhart et al., 2011). Also, the students did not complete their end products within the time frame set by their teacher, which is another indicator that the learning processes was not supported effectively in this case.

Therefore, based on the students' learning processes in case $\mathrm{C} 2$, it can be useful to organize the follow-up work as a three-step process: first, a learning task requiring students to make a decision to a real-life dilemma, and justify their choice with field data. Then, they are prepared for making an end product requiring more procedural skills (Remmen \& Frøyland, 2015). Finally, presenting the end product would be the third step in which students demonstrate their learning outcome to their teacher and peers.

\section{RECOMMENDATIONS FOR FIELDWORK RECONSIDERED}

In spite of having six cases on the outset, we found only one case that: (1) thinking moves were prominent in the student learning processes and, (2) the teacher was satisfied with the learning tasks and the students' learning outcome. Therefore, we advocated a need for reconsidering the well-known recommendations in the literature. The discussion of the students' learning processes in case C2 and B2 provides a starting point for suggesting alternative recommendations that teachers and educators can use to design preparation, fieldwork, and follow-up work. Specifically, we recommend teachers to consider:

- Situating the (geo) scientific content in a real-life issue that requires students to form an opinion or suggest a solution. Then, the purpose of the fieldwork can be to collect field observations students need to solve the issue and justify their conclusions.

- Providing students with "tools for observation and interpretation" before collecting observations in the field. Such tools can support their thinking because they know what features to look for and what it means in a (geo) scientific sense.

- Conducting fieldwork close to the school. This can be more powerful if the field data that is collected shall be used to suggest solutions to real-life issues.

- Providing students with one, focused field task that allow them to make a choice based on comparison of a limited number of alternatives.

- Organizing follow-up work as a three-step process. First, a learning task requiring students to interpret their field observation in order to make a decision. Second, allow students to make the end product requiring more procedural skills, and finally, present their results in end products.

\section{REFERENCES}

Bamberger, Y., \& Tal, T. (2007). Learning in a personal context: Levels of choice in a free choice learning environment in science and natural history museums. Science Education, 91 (1), 75-95.

Bennett, J., Lubben, F., \& Hogarth, S. (2007). Bringing science to life: A synthesis of the research evidence on the effects of context-based and STS approaches to science teaching. Science Education, 91(3), 347-370.

Braund, M., \& Reiss, M. (2006). Towards a More Authentic Science Curriculum: The contribution of out-of-school learning. International Journal of Science Education, 28(12), 1373-1388. 
Crawford, B. (2014). From inquiry to scientific practices in the science classroom. In N. Lederman \& S. Abell (Eds.), Handbook of Research on Science Education, Vol II. New York: Routledge.

Derry, S.J., Pea, R.D., Barron, B., Engle, R.A., Erickson, F., ..., Sherin, M.G. (2010). Conducting video research in the learning sciences: Guidance on selection, analysis, technology, and ethics. Journal of the Learning Sciences, 19(1), 3-35.

DeWitt, J., \& Osborne, J. (2007). Supporting teachers on science-focused school-trips: towards an integrated framework of theory and practice. International Journal of Science Education, 26 (6), 685-710.

DeWitt, J., \& Storksdieck, M. (2008). A short review of school field trips: key findings from the past and implications for the future. Visitor Studies, 11(2), 181-197.

DeWitt, J., \& Hohenstein, J. (2010). School Trips and Classroom Lessons: An Investigation into Teacher-Student Talk in Two Settings. Journal of Research in Science Teaching, 47(4), 454-473.

Engle, R., \& Conant, F.R. (2002). Guiding principles for fostering productive disciplinary engagement: Explaining an emergent argument in a community of learners classroom. Cognition and Instruction, 20: 399-483.

Entwistle, N., \& Smith, C. (2002). Personal understanding and target understanding: Mapping influences on the outcomes of learning. British Journal of Educational Psychology, 72, 321-342.

Ford, D.J. (2005). The challenges of observing geologically: Third graders descriptions of rock and mineral properties. Science Education, 89(2), 276-295.

Frøyland, M. (2010). Mange erfaringer i mange rom. Oslo: Abstrakt forlag.

Kent, M., Gilbertson, D.D., \& Hunt, C.O. (1997). Fieldwork in geography teaching: A critical review of the literature and approaches. Journal of Geography in Higher Education. 21, 313-332.

Knain, E. \& Prestvik, O. (2006). 'Scientific literacy' nedfelt i geofagene. NorDiNa 1, 18-27.

Koller, K. (2009). Uteskole = praksis + teori: en studie av muligheter og utfordringer med uteskole i naturfag på videregående trinn 1. (Unpublished Master's thesis), Institute of mathematics, science and technology, section for teacher education, University of Life sciences, Ås, Norway.

Magntorn, O. \& Helldén, G. (2006). Reading Nature - experienced teachers' reflections on a teaching sequence in ecology: implications for future teacher training. NorDiNa, 5, 67-81.

Mogk, D.W., \& Goodwin, C. (2012). Learning in the field: Synthesis of research on thinking and learning in the geosciences. In K.A. Kastens \& C.A. Manduca (Eds.), Earth and Mind II: A synthesis of research on thinking and learning in the geoscience (pp. 131-163). Geological Society of America special paper 486.

Morag, O. \& Tal, T. (2012). Assessing Learning in the Outdoors with the Field Trip in Natural Environments (FiNE) Framework. International Journal of Science Education 34(5), 745-777.

Oost, K., DeVries, B., \& Van der Schee, J.A. (2011). Enquiry-driven fieldwork as a rich and powerful teaching strategy-school practices in secondary geography education in the Netherlands. International Research in Geography and Environmental Education, 20(4), 309-325.

Orion, N. (1993). A model for the development and implementation of field trips as an integral part of the science curriculum, School Science and Mathematics, 93, 325-331.

Remmen, K.B, \& Frøyland, M. (2013). How students can be supported to apply geoscientific knowledge learned in the classroom to phenomena in the field: An example from high school students in Norway. Journal of Geoscience Education, 61(4), 437-452.

Remmen, K.B, \& Frøyland, M. (2014). Implementation of guidelines for effective fieldwork designs: Exploring learning activities, learning processes, and student engagement in the classroom and the field. International Research in Geographical and Environmental Education, 23(2), 103125 .

Remmen, K.B, \& Frøyland, M. (2015). What happens in classrooms after earth science fieldwork? Supporting student learning processes during follow-up activities. International Research in Geographical and Environmental Education, 24 (1), 24-42.

Rickinson, M., Dillon, J., Teamey, K., Morris, K., Choi, M.Y, Sanders, D., \& Benefield, P. (2004). A Review of Outdoor Learning. Schrewsbury, UK: Field studies council, 8. National Foundation of Educational Research. 
Ritchhart, R., Church, M., \& Morrison, K. (2011). Making thinking visible: How to promote engagement, understanding, and independence for all learners. San Francisco, CA: Jossey-Bass.

Scott, G.W., Boyd, M., Scott, L., \& Colquhoun, D. (2014). Barriers to biological fieldwork: What really prevents teaching out of doors? Journal of Biological Education, DOI: 10.1080/00219266.2014.914556

Tal, T., Alon, N.L., \& Morag, O. (2014). Exemplary practices in field trips to natural environments. Journal of Research in Science Teaching, 51(4), 430-461.

Wiske, M.S. (Ed.). (1998). Teaching for Understanding. Linking research with practice. San Francisco: Jossey-Bass.

Ødegaard, M. (2007). Naturfag til nytte og glede! Naturvitenskapelig allmenndannelse ved dramatiske virkemidler. NorDiNa, 3, 76-85. 